\title{
RANCANG BANGUN APLIKASI E-BUDGETING UNTUK MENGONTROL ANGGARAN PENDAPATAN DAN BELANJA UNIVERSITAS MURIA KUDUS BERBASIS WEB
} (STUDI KASUS FAKULTAS TEKNIK UNVIERSITAS MURIA KUDUS)

\author{
Rully Khoirul Anwar \\ Fakultas Teknik, Program Studi Teknik Informatika \\ Universitas Muria Kudus \\ Email: rullykhoirulanwar@gmail.com \\ Tri Listyorini \\ Fakultas Teknik, Program Studi Teknik Informatika \\ Universitas Muria Kudus \\ Email: trilistyorini@umk.ac.id
}

\begin{abstract}
ABSTRAK
Universitas sebagai institusi tertinggi penyelenggara pendidikan tertinggi sudah seharusnya mampu mengelola keuangan dengan sebaik - baiknya. Namun dewasa ini masih sering ditemukan kendala di lapangan. Hal ini dikarenakan belum adanya system yang mampu untuk mengelola keuangan tersebut, sehingga masih banyak sekali masalah yang dihadapi oleh universitas diantaranya permasalahan dalam hal pengarsipan, pendataan rencana anggaran, hingga hilangnya dokumen fisik karena system yang ada masih manual. Bermula dari hal dibuatlah aplikasi Rancang Bangun Aplikasi E-Budgeting untuk mengontrol Anggaran Pendapatan dan Belanja Universitas Muria Kudus berbasis Web (Studi Kasus Fakultas Teknik Unviersitas Muria Kudus). Diharapkan dengan aplikasi ini dapat mengatasi permasalahan tersebut.
\end{abstract}

Kata kunci: sistem; anggaran pendapatan dan belanja; e-budgeting.

\begin{abstract}
The university as the highest institution providing the highest education should be able to manage finances as well as possible. But today there are still many obstacles in the field. This is because there is no system that is able to manage the finances, so that there are still many problems faced by universities including problems in archiving, data collection of budget plans, to the loss of physical documents because the system is still manual. Starting from the case, the application of E-Budgeting Application Design was made to control the Muria Kudus University-based Web Revenue and Expenditure (Case Study of the Faculty of Engineering, Muria Kudus University). It is expected that this application can overcome these problems
\end{abstract}

Keywords: system; revenue and expenditure budget; e-budgeting.

\section{PENDAHULUAN}

Pada saat sekarang ini, Anggaran Pendapatan dan Belanja Universitas (APBU) masih menggunakan sistem lama yaitu melakukan pembukuan dalam bentuk fisik, hal ini dapat menimbulkan berbagai masalah dikemudian hari. Sistem seperti ini ini sudah dianggap tidak efisien lagi, untuk mengatasi permasalahan tersebut. Untuk mengatasi permasalahan tersebut diperlukan sebuah system yang terintegrasi yang bersifat non fisik dan berbasis web.

Dengan menggunakan system ini dimaksudkan untuk kebutuhan dalam penyampaian dan pengelolaan informasi data keuangan dapat lebih cepat dan tepat, sehingga tidak perlu lagi khawatir apabila dikemudian hari kehilangan data. [1][2].

Kemudahan pengguna untuk mengelola laporan keuangan menjadi suatu hal yang perlu diperhatikan. Selain karena beberapa alasan tersebut, pembuatan system ini nantinya juga akan membantu pihak manajemen dalam mengontrol pengeluaran anggaran. Bermula dari permasalahan tersebut maka diusulkan adanya pembaharuan sistem lama kedalam sistem informasi yang baru dengan teknologi komputer berbasis web. [3][4]. 
Hal ini yang menarik peneliti untuk mengangkat judul "Rancang Bangun Aplikasi E-Budgeting untuk mengontrol Anggaran Pendapatan dan Belanja Universitas Muria Kudus berbasis Web (Studi Kasus Fakultas Teknik Unviersitas Muria Kudus)". Aplikasi ini merupakan alat bantu untuk mempermudah pengguna dalam mengelola data Anggaran Pendapatan dan Belanja Universitas di Fakultas Teknik Universitas Muria Kudus. Sistem database realtime ini dirasa sangat efektif karena dirancang untuk memberikan informasi yang akurat tentang detail pengeluaran anggaran, sehingga user dapat mengetahui rinciannya masing - masing..

\section{METODOLOGI PENELITIAN}

\subsection{Metode Pengumpulan Data}

a. Studi Kepustakaan

Studi kepustakaan dalam penelitian ini, pengumpulan data dilakukan dengan cara mencari informasi melalui buku, literatur, jurnal, karya ilmiah, majalah, koran dan lainnya yang berhubungan dengan objek penelitian dengan tujuan membentuk suatu landasan teori. Dalam studi kepustakaan juga mengumpulkan jurnal-jurnal yang berkaitan dengan penelitian ini. Seperti penelitian yang dilakukan di Universitas Muria Kudus tentang aplikasi manajemen unit kemahasiswaan berbasis web [5]. Yang kedua adalah penelitian yang sama dilakukan di Universitas Muria Kudus yaitu pengembangan digital library untuk Fakultas Teknik UMK [6] serta web arsip dinamis di Universitas Muria Kudus juga [7]. Yang terakhir adalah penelitian yang membahas tentang implementasi tracer studi pada program studi Teknik Informatika Universitas Muria Kudus [8].

b. Studi Dokumentasi

Studi dokumen merupakan pelengkap dari penggunaan metode observasi dan wawancara dalam penelitian kualitatif [9]. Pada studi ini, dikumpulkan data-data yang berkaitan dengan perekapan tentang anggaran pendapatan dan belanja Universitas Muria Kudus.

\subsection{Metode Pengembangan Sistem}

Metode air terjun sering dikenal dengan metode waterfall atau dinamakan siklus hidup klasik (classic life cycle), Metode ini menjelaskan tentang alur pembuatan sistem secara sistematis dan juga berurutan pada pengembangan perangkat lunak, diawali dengan menentukan spesifikasi kebutuhan yang dibutuhkan oleh pengguna kemudian melewati beberapa proses seperti perencanaan (planning), permodelan (modeling), konstruksi (construction), serta penyerahan sistem ke para pengguna (deployment) dan diakhiri dengan dukungan pada perangkat lunak lengkap yang dihasilkan [10]. Tahapan metode waterfall dapat dilihat pada gambar di bawah ini:

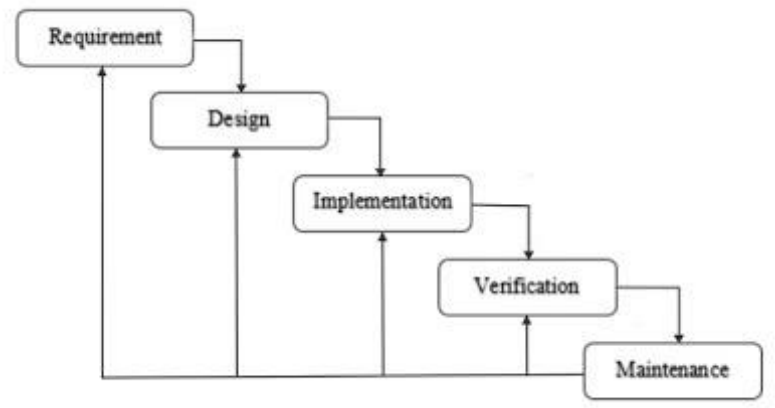

Gambar 1. Metode waterfall

a. Requirement

Pada tahap ini diperlukan analisa pengembang sistem dengan cara berkomunikasi langsung dengan pengguna untuk memahami perangkat lunak yang diharapkan. Kemudian informasi dianalisisa untuk menentukan kebutuhan yang dibutuhkan oleh pengguna.

b. Perancangan Sistem (Design)

Perancangan sistem dilakukan ketika requirement sudah pasti dan jelas.

c. Implementasi (Implementation) 
Pada tahap ini, sistem mulai dikembangkan dalam program kecil yang dinamakan unit, sistem ini nantinya dapat diintegrasi dalam tahap selanjutnya. Selanjutnya setiap unit system kemudian diuji untuk fungsionalitas yang disebut sebagai unit testing.

d. Verifikasi (Verification)

Setelah pengujian yang dilakukan masing-masing unit, seluruh sistem diuji untuk mengecek adanya kegagalan maupun kesalahan.

e. Pemeliharaan (Maintenance)

Pemeliharaan berfungsi untuk menemukan dan memperbaiki kesalahan yang tidak ditemukan pada langkah sebelumnya.

\section{HASIL DAN PEMBAHASAN}

\subsection{Analisa Proses}

Dalam analisa proses langkah awal yang dibuat adalah context diagram. Pada context diagram yang tergambar pada Gambar 2, menjelaskan proses e-budgeting memiliki 4 entitas yaitu super admin, admin, pimpinan dan user. Di mana setiap alur dari proses ke entitas menjelaskan arus proses sistem e-budgeting tersebut. Dari contexs diagram ini terurai pada arus DFD level 0. Pada DFD level 0 proses e-budgeting terbagi menjadi 4 proses yaitu data user, data APBU, data anggaran dan pengajuan. Dalam level ini terdapat arus yang sampai pada penyimpanan, terlihat pada Gambar 3.

Perancangan yang tertuang pada DFD level 0 dilanjutkan dengan Entity Relationship Diagram (ERD) seperti pada Gambar 4. Pada ERD e-budgeting ini menjelaskan 14 entitas yang masing-masing memiliki relasi dan atribut sendiri. Hal ini dilakukan untuk menyusun tabel untuk penyimpanan data ebudgeting.

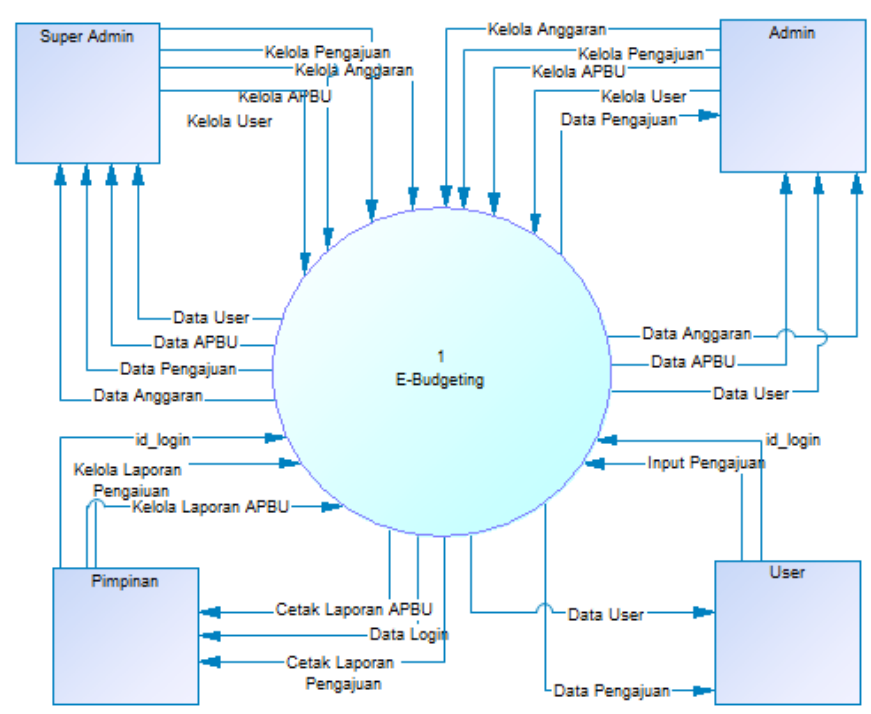

Gambar 2. Context Diagram 


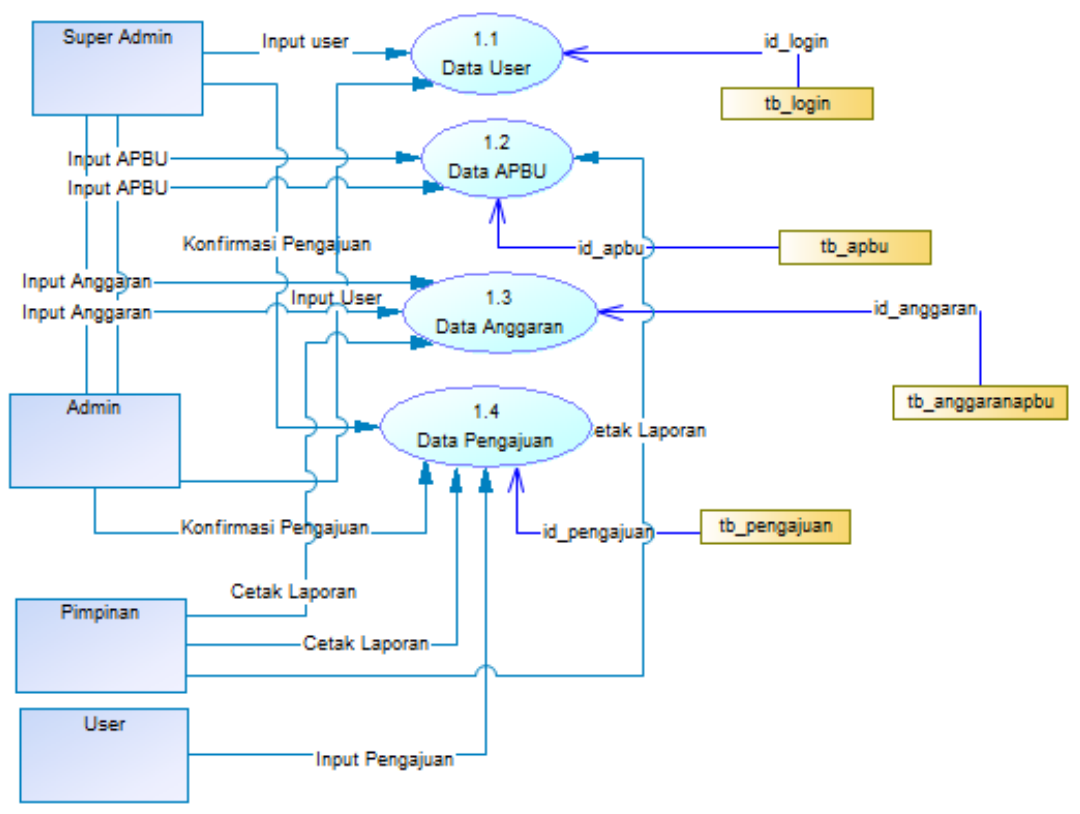

Gambar 3. DFD Level 0

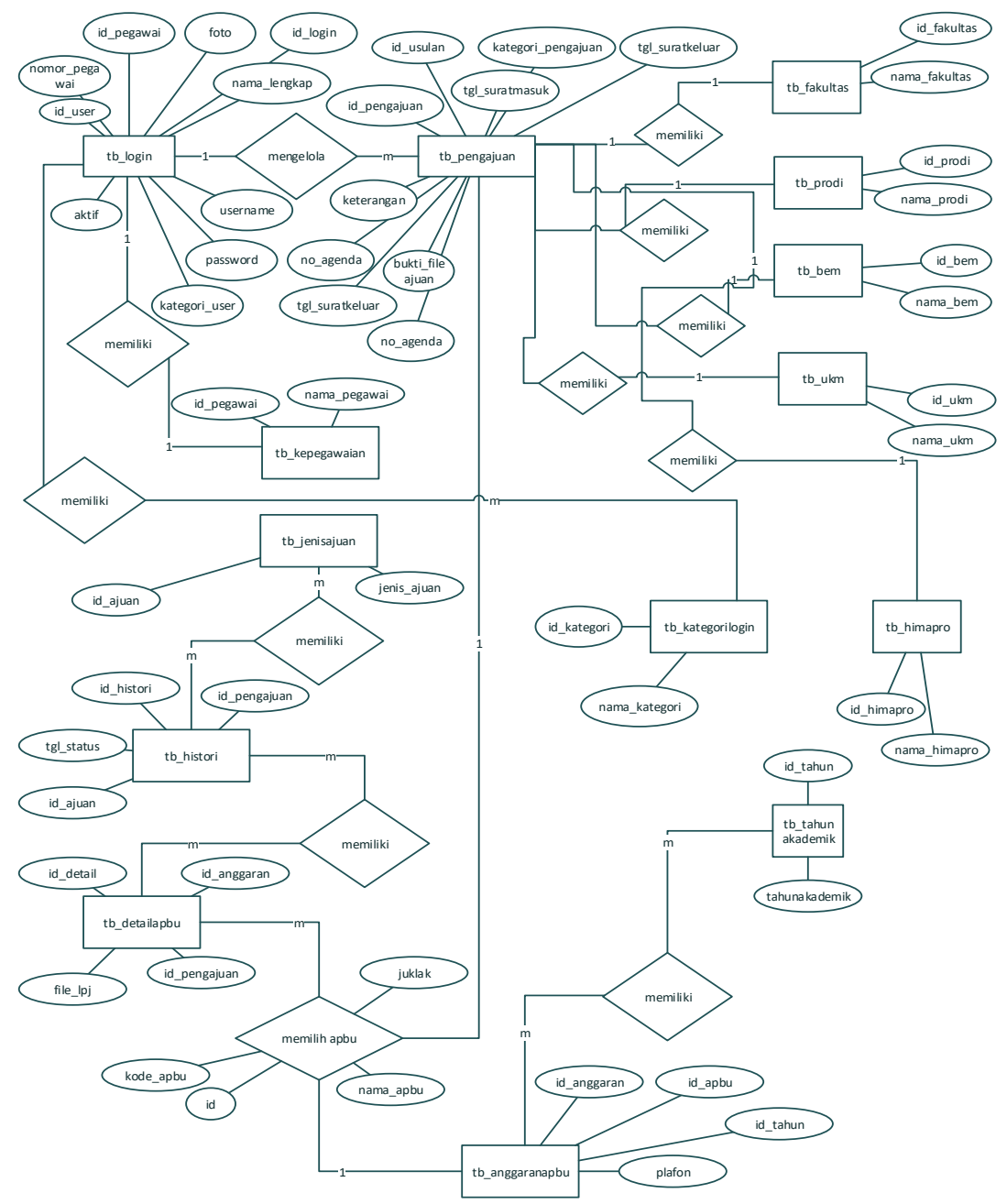

Gambar 4. ERD 


\subsection{Rancangan Tabel Database}

Pada rancangan tabel di dalam database, terdapat 18 tabel yang memiliki field di masing-masing tabelnya. Tidak semua tabel berelasi, seperti tb_kepegawaian, tb_himapro, tb_detailapbu, info_penting, tb_jenisajuan, tb_bem, dan tb_ukm. Selain tabel tersebut satu tabel dengan tabel yang lain saling berelasi. Hal ini dapat dilihat pada Gambar 5.

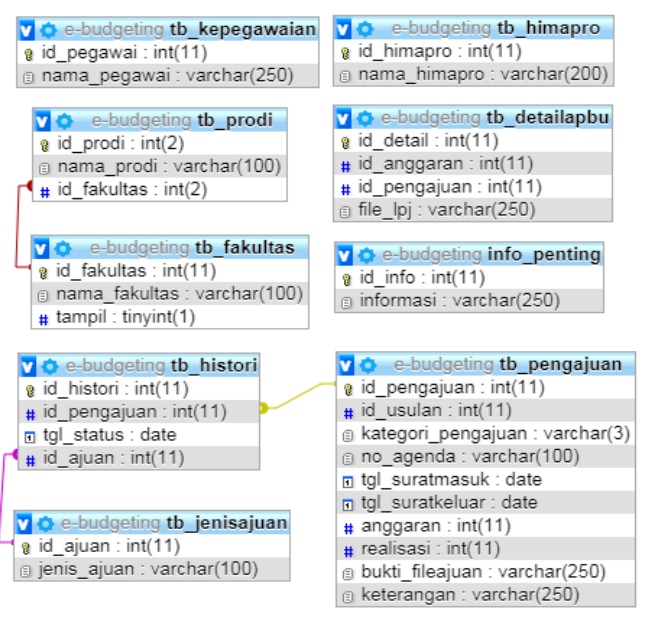

Gambar 5. Relasi Antar Tabel

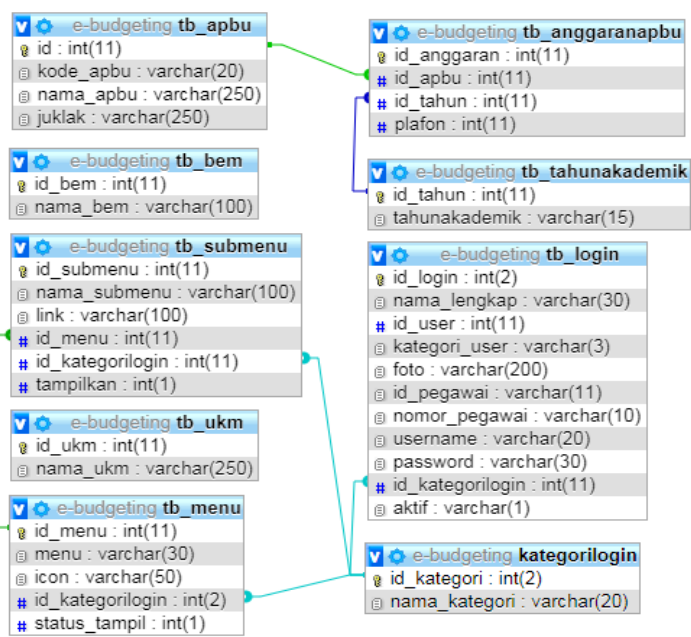

id_anggaran : int(11)

\# id_apbu : int(11)

\# plafon : int(11)

foto : $\operatorname{varchar}(200)$

id_pegawai : varchar(11)

password : $\operatorname{varchar}(30)$

o-budgeting kategorilogin nama kategori : varchar(20)

\subsection{Halaman Struktur Menu}

Form login ini digunakan untuk mengkases kedalam sistem E-Budgeting Fakultas Teknik Universitas Muria Kudus. Sistem akan secara otomatis mendeteksi pengguna yang sedang login menggunakan username dan password yang digunakan. Apabila akun pengguna tidak ditemukan atau sudah dinonaktifkan oleh super admin maka akan muncul kotak pesan "Akun anda dinonaktifkan". Form login dapat dilihat pada Gambar 6.

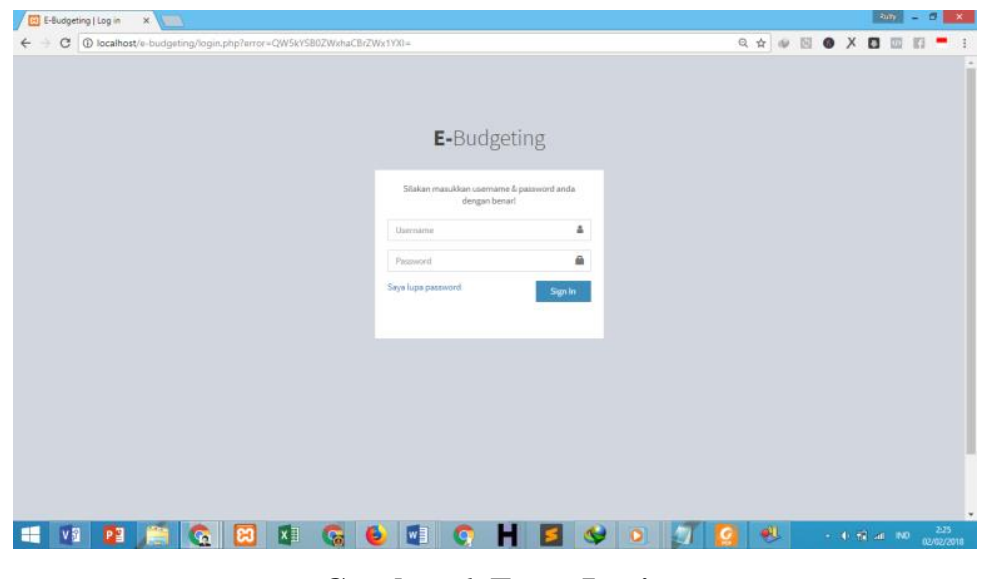

Gambar 6. Form Login

Form Beranda Admin ini menampung informasi jumlah pengajuan secara keseluruhan, jumlah pengajuan disetujui, ditolak, dan pengajuan yang berstatus pending. Pada form ini juga dilengkapi dengan grafik pengajuan. Grafik ini berfungsi sebagai alat untuk mengukur banyaknya pengajuan setiap tahun akademik. Form beranda admin dapat terlihat pada Gambar 7 . 


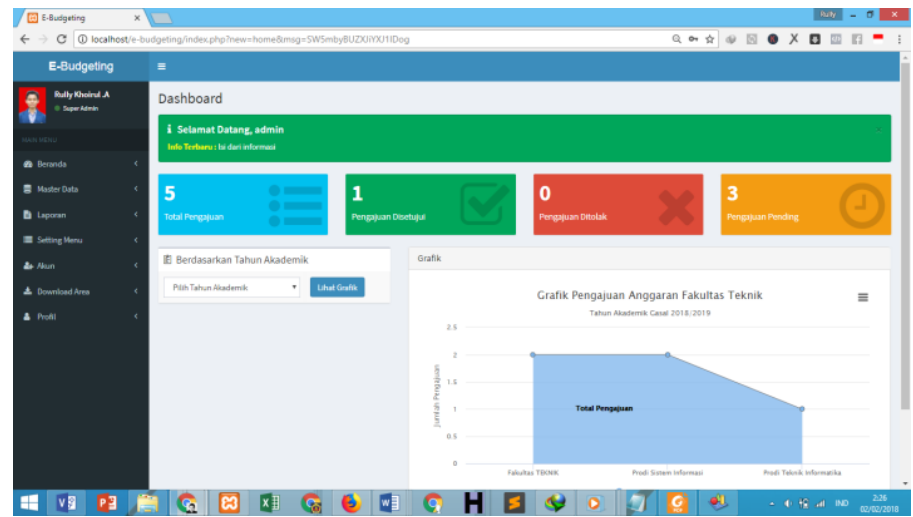

Gambar 7. Form Beranda Admin

Hampir sama dengan form beranda admin, perbedaannya adalah pada form beranda user ini hanya menampilkan data pengajuan dari masing - masing user. Sehingga data yang lebih spesifik. Seperti yang terlihat pada Gambar 8

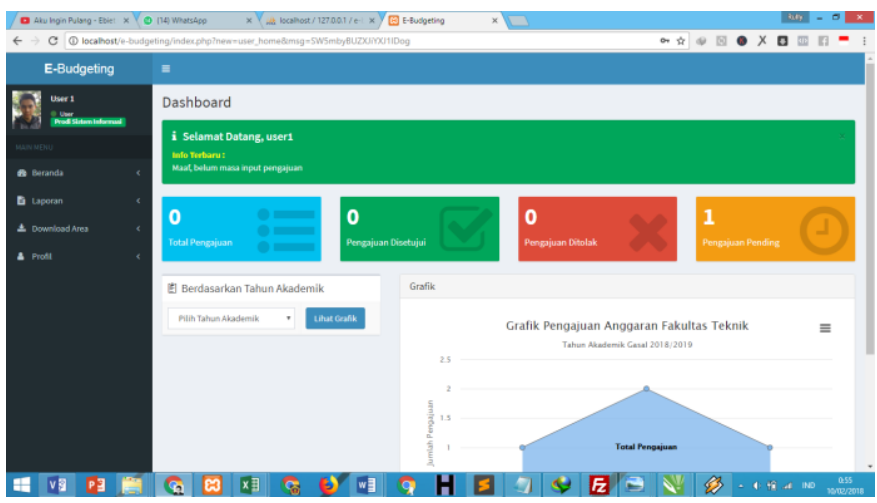

Gambar 9. Form Beranda User

Pada Gambar 10 terlihat form kelola APBU, di mana menampung data RAPBU secara keseluruhan. Dilengkapi juga dengan tombol proses pengajuan untuk memproses pengajuan yang telah diajukan oleh pengguna lain.

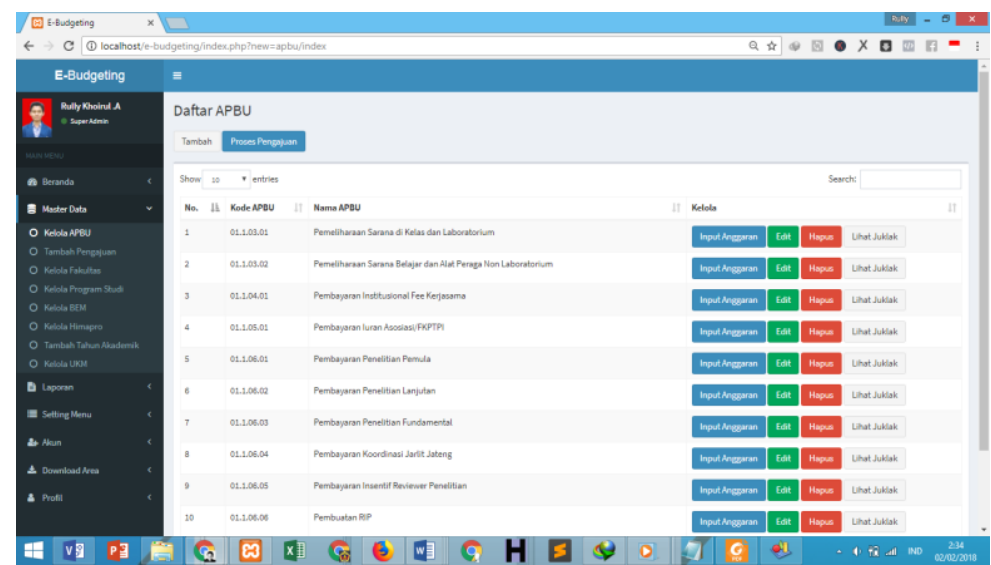

\section{Gambar 10. Form Kelola APBU}

Form tambah pengajuan seperti terlihat pada Gambar 11 ini berfungsi untuk menginput pengajuan pengajuan. Data pengajuan yang ditampilkan berdasarkan RAPBU sehingga mempermudah pengguna untuk mencari pengajuan berdasarkan RAPBU yang sudah ada. 


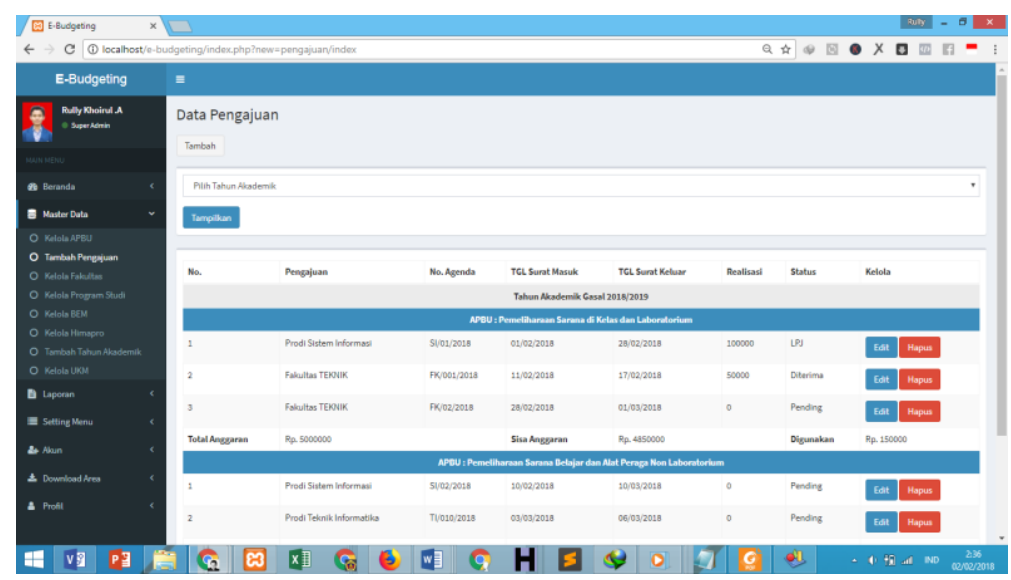

Gambar 11. Form Tambah Pengajuan

Form tambah tahun akademik ini digunakan untuk mengelola tahun akademik. Pengguna bisa menambahkan, merubah dan menghapus tahun akademik yang sudah ada. Hal ini dapat dilihat pada Gambar 12.
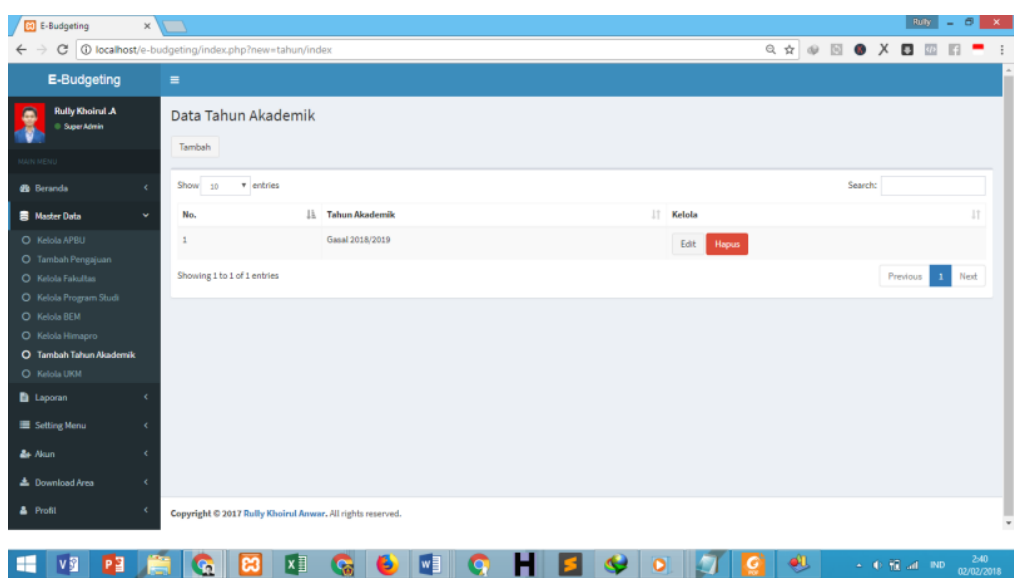

Gambar 12. Form Tambah Tahun Akademik

Pada form anggaran APBU pada Gambar 13 ini, pengguna dapat memasukkan plafon yang telah disediakan.
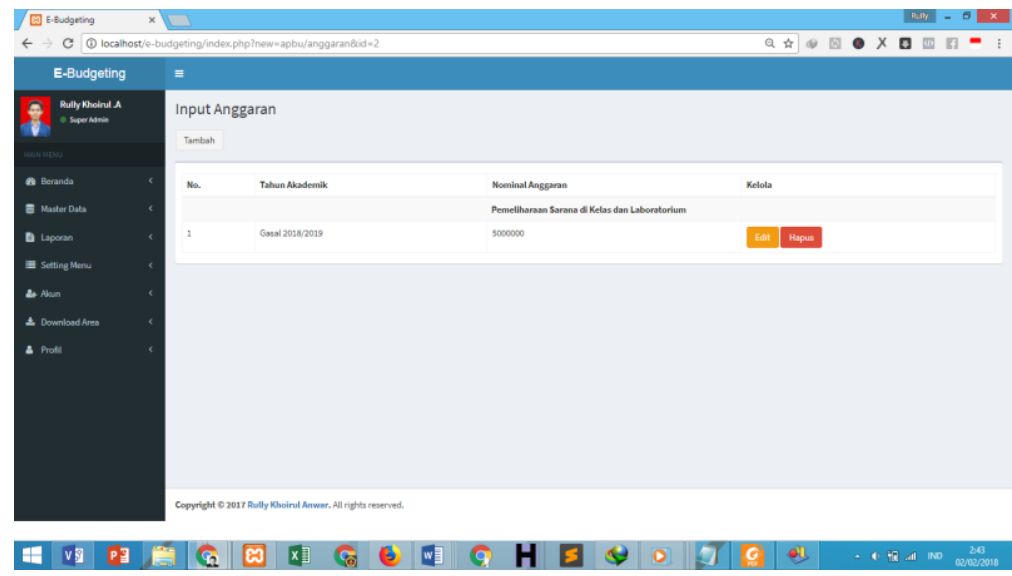

Gambar 13. Form Anggaran APBU

Pada form ini, pengguna dapat menyetujui ataupun menolak pengajuan yang telah diajukan dari masing - masing program studi. Pengguna juga bisa melihat riwayat penyetujuan pengajuan dengan menekan tombol klik pada status berwarna biru, maka nanti akan muncul secara otomatis. Form proses pengajuan dapat dilihat pada Gambar 14. 

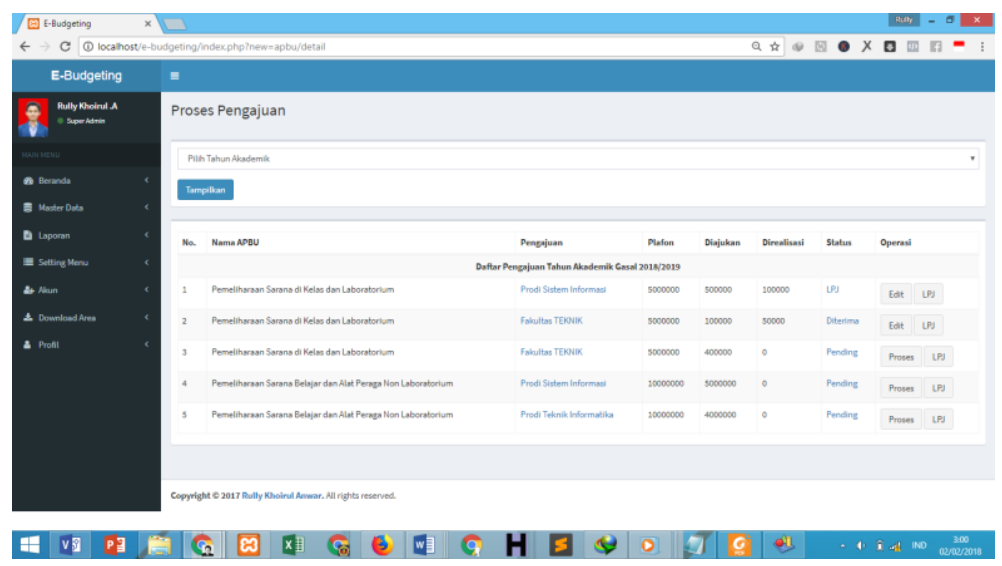

\section{Gambar 15. Form Proses Pengajuan}

Form ini berfungsi untuk membantu pengguna untuk mencetak laporan pengajuan selama masa tahun akademik tertentu. Pengguna juga dapat mengunduh laporan pengajuan tersebut dengan format ekstensi .xls melalui fitur "Export to Excel". Form cetak laporan pengajuan ini dapat dilihat pada Gambar 16.

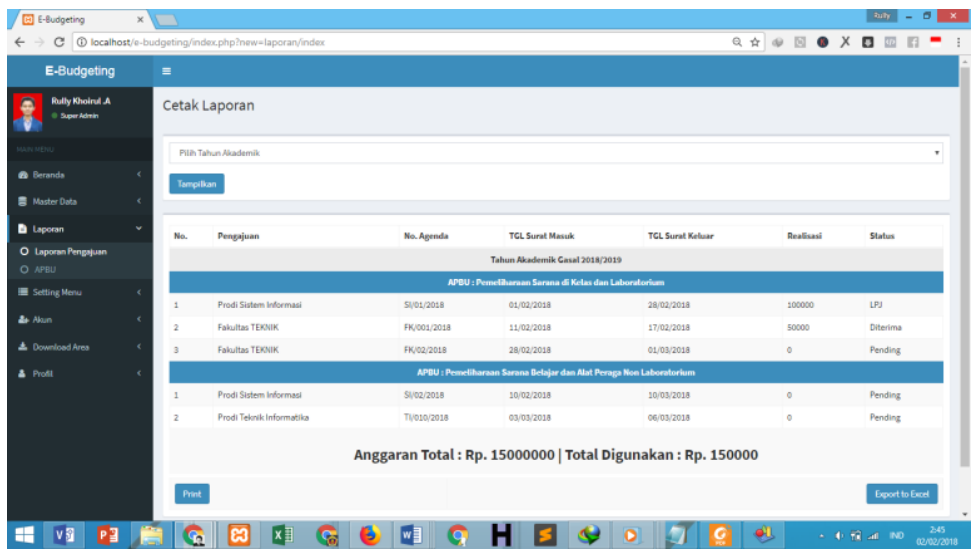

Gambar 16. Form Cetak Laporan Pengajuan

Pada Gambar 17 memperlihatkan form cetak laporan APBU ini, pengguna dapat mencetak RAPBU pada tahun akademik yang telah ditentukan. Pengguna dapat mencetaknya langsung maupun mengunduh data berekstensi .xls.

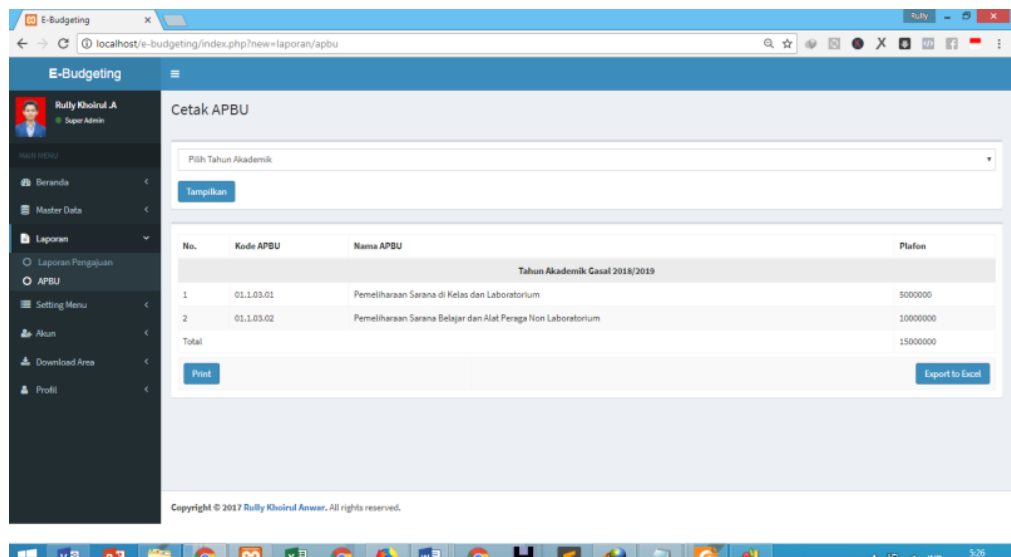

Gambar 17. Form Cetak Laporan APBU

Gambar 18 memperlihatkan form kelola menu ini berfungsi untuk memberikan batasan hak akses pada setiap level akun yang berbeda. 


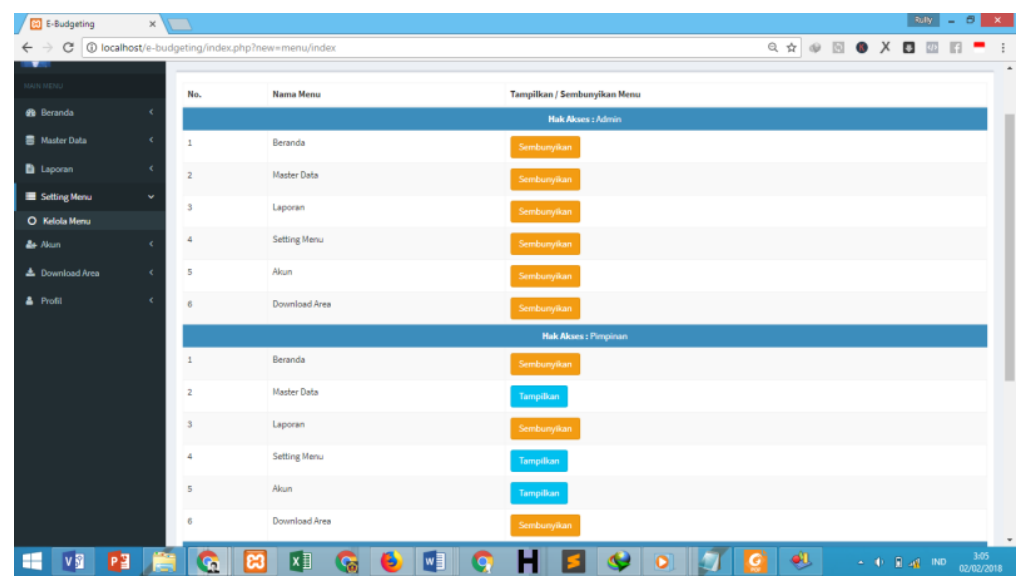

Gambar 18. Form Kelola Menu

Pada aplikasi e-budgeting ini juga dilengkapi dengan form download file pengejuan. Hal ini memudahkan pengguna untuk mengunduh bukti file pengajuan yang dilampirkan saat pengajuan. File tersebut berekstensi .pdf. form download file pengajuan dapat dilihat pada Gambar 19.

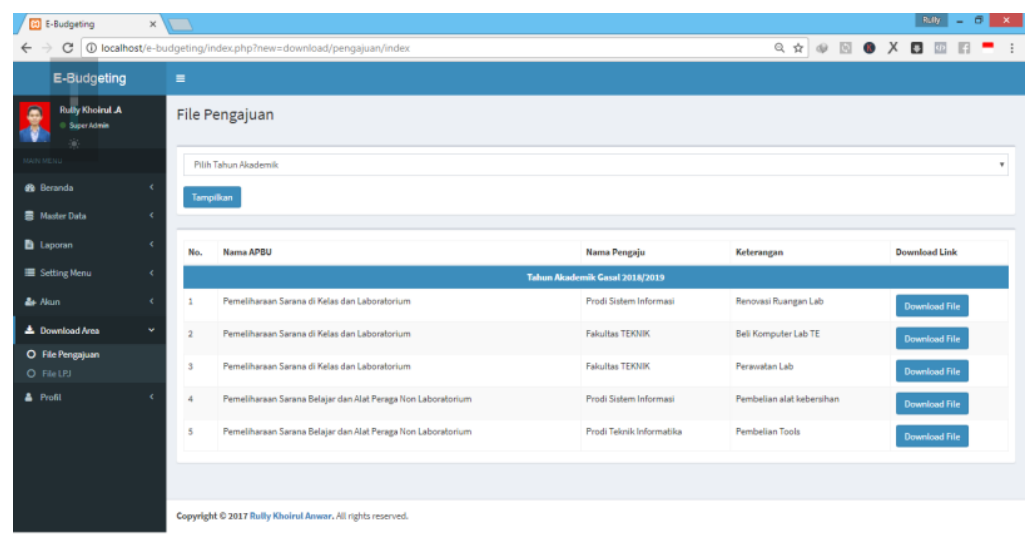

Gambar 19. Form Download Pengajuan

Pada Form download LPJ, pengajuan yang sudah disetujui dan di LPJ maka sistem akan otomatis. Apabila ditemukan pengajuan yang belum di LPJ maka link download file LPJ akan berganti status menjadi "Link tidak tersedia". Hal ini ditunjukkan pada Gambar 20.

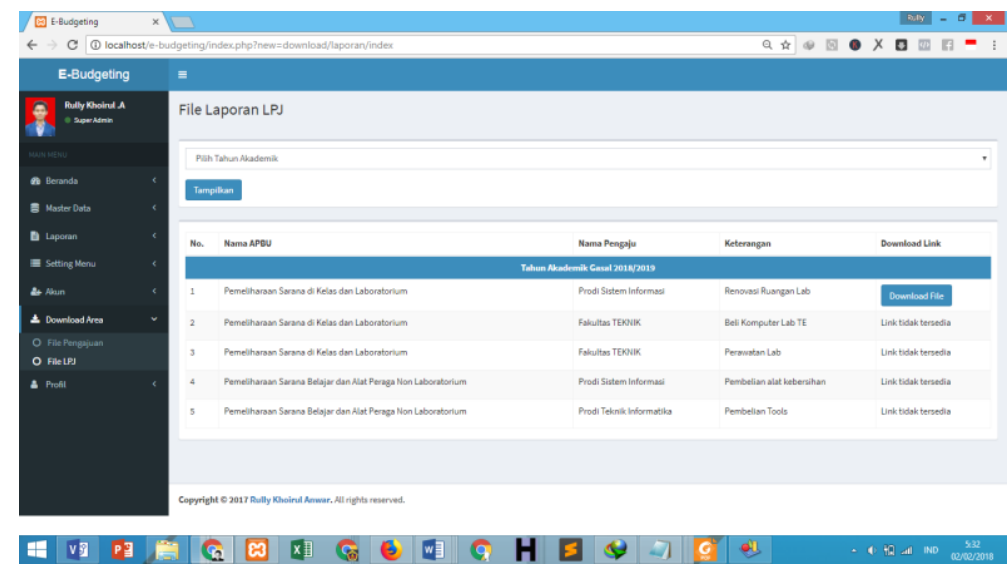

Gambar 20. Form Download LPJ

Form kelola akun ini memiliki fungsi untuk mengotrol akun. Pengguna dapat menonaktifkan dan mengaktifkan akun kembali di form ini. Pengguna juga dapat menambah, mengubah ataupun menghapus 
data akun tersebut apabila status pengguna tersebut adalah admin. Form kelola akun ini terlihat pada Gambar 21.

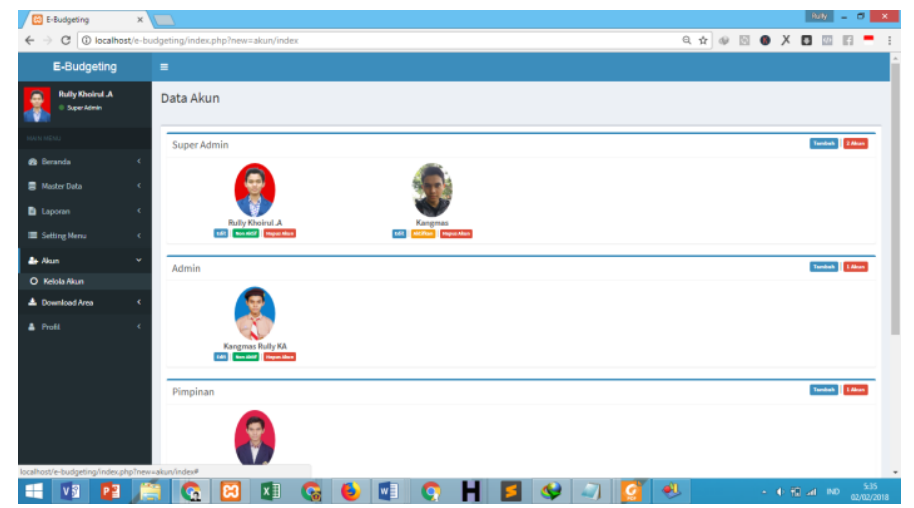

Gambar 21. Form Kelola Akun

\section{KESIMPULAN}

Dari hasil penelitian dan pembahasan dapat ditarik kesimpulan, pada penelitian ini berhasil membangun aplikasi E-Budgeting berbasis web untuk mengotrol Anggaran Pendapatan dan Belanja Universitas di Fakultas Teknik Universitas Muria Kudus yang interaktif dengan menggunakan metode pengembangan Software Development Life Cycle (SDLC). Yang kedua aplikasi E-Budgeting berbasis web ini berjalan sesuai harapan, semua tombol menu berfungsi sesuai fungsinya serta aplikasi berjalan dengan lancar di komputer dan di harapkan dapat bermanfaat untuk mempermudah pembuatan laporan keuangan di Fakultas Teknik Universitas Muria Kudus. Serta aplikasi yang dikhususkan untuk Fakultas Teknik Universitas Muria Kudus dan dibuat menggunakan bahasa pemrograman PHP. Oleh karena itu aplikasi ini diupload di hosting, sehingga apabila dibutuhkan aplikasi tersebut bisa digunakan kapanpun dan dimanapun dengan cara mengakses situs aplikasi tersebut menggunakan perangkan komputer yang telah terhubung dengan internet.

\section{UCAPAN TERIMA KASIH}

Terima kasih kepada Program Studi Teknik Informatika Universitas Muria Kudus yang telah memfasilitasi penelitian ini, serta memberikan ijin untuk melakukan survei di Fakultas Teknik Universitas Muria Kudus.

\section{DAFTAR PUSTAKA}

[1] P. E. B, "E-Budgeting Aplikasi Pengelolaan Keuangan Desa Berbasis Web dengan Metode Pengembangan Inkremental di Pemerintahan Kabupaten Pati," Universitas Dian Nuswantoro, Semarang, 2017.

[2] Zarnelly, "Sistem Informasi E-Budgeting menggunakan Pendekatan Berorientasi Objek (Studi Kasus: UIN SUSKA Riau),” J. Ilm. Rekayasa Dan Manaj. Sist. Inf., vol. 3, pp. 70-77, 2017.

[3] A. S, "E-Budgeting (Studi Kasus Pada Dinas Pendapatan dan Pengelolaan Keuangan Kota Surabaya)," Universitas Gadjah Mada, Yogyakarta, 2016.

[4] Arbie E, Pengantar Sistem Informasi Manajemen. Jakarta: Bina Alumni Indonesia, 2000.

[5] Agung Rifqi Hidayat, Tri Listyorini, and Tutik Khotimah, "Aplikasi Manajemen Unit Kegiatan Mahasiswa pada Universitas Muria Kudus Berbasis Web," in SNATIF (Seminar Nasional Teknologi dan Informasi, Kudus, 2015, pp. 389-394.

[6] T. Listyorini and M. Iqbal, "PERANCANGAN PENGEMBANGAN DIGITAL LIBRARY BERBASIS WEB RESPONSIVE,” Simetris J. Tek. Mesin Elektro Dan Ilmu Komput., vol. 6, no. 1, p. 69, Apr. 2015.

[7] Christian Sutanto and Tri Listyorini, "Aplikasi Web Arsip Dinamis Perpustakaan Unviersitas Muria Kudus," in SNATIF (Seminar Nasional Teknologi dan Informasi, Kudus, 2015.

[8] Esti Wijayanti, Tri Listyorini, and Tutik Khotimah, "Implementasi Tracer Study Program Studi Teknik Informatika Universitas Muria Kudus Berbasis Aplikasi Web," presented at the Semnasteknomedia Online, Yogyakarta, 2017, vol. 5, pp. 145-150.

[9] Sugiyono, Metode Penelitian Bisnis. Bandung: Alfabeta, 2013.

[10] R. Pressman, Rekayasa Perangkat Lunak: pendekatan praktisi, Buku 1. Yogyakarta: Andi Offset, 2007. 